USAWC STRATEGY RESEARCH PROJECT

\title{
GLOBALIZATION AND THE MILITARY INDUSTRIAL BASE: WHERE SHOULD U.S. POLICY GO?
}

\author{
by \\ Mr. Dennis R. Sundell \\ Department of Army Civilian
}

\author{
Colonel William Braun \\ Project Adviser
}

This SRP is submitted in partial fulfillment of the requirements of the Master of Strategic Studies Degree. The U.S. Army War College is accredited by the Commission on Higher Education of the Middle States Association of Colleges and Schools, 3624 Market Street, Philadelphia, PA 19104, (215) 662-5606. The Commission on Higher Education is an institutional accrediting agency recognized by the U.S. Secretary of Education and the Council for Higher Education Accreditation.

The views expressed in this student academic research paper are those of the author and do not reflect the official policy or position of the Department of the Army, Department of Defense, or the U.S. Government. 


\section{Report Documentation Page}

Form Approved

OMB No. 0704-0188

Public reporting burden for the collection of information is estimated to average 1 hour per response, including the time for reviewing instructions, searching existing data sources, gathering and maintaining the data needed, and completing and reviewing the collection of information. Send comments regarding this burden estimate or any other aspect of this collection of information,

including suggestions for reducing this burden, to Washington Headquarters Services, Directorate for Information Operations and Reports, 1215 Jefferson Davis Highway, Suite 1204, Arlington

VA 22202-4302. Respondents should be aware that notwithstanding any other provision of law, no person shall be subject to a penalty for failing to comply with a collection of information if it

does not display a currently valid OMB control number.

1. REPORT DATE

30 MAR 2007

4. TITLE AND SUBTITLE

Globalization and the Military Industrial Base Where Should U.S. Policy

Go?

6. $\operatorname{AUTHOR}(\mathrm{S})$

Dennis Sundell

7. PERFORMING ORGANIZATION NAME(S) AND ADDRESS(ES)

U.S. Army War College,Carlisle Barracks,Carlisle,PA,17013-5050

9. SPONSORING/MONITORING AGENCY NAME(S) AND ADDRESS(ES)
2. REPORT TYPE

Strategy Research Project
3. DATES COVERED

00-00-2006 to 00-00-2007 5a. CONTRACT NUMBER

5b. GRANT NUMBER

5c. PROGRAM ELEMENT NUMBER

5d. PROJECT NUMBER

5e. TASK NUMBER

5f. WORK UNIT NUMBER

8. PERFORMING ORGANIZATION

REPORT NUMBER

10. SPONSOR/MONITOR'S ACRONYM(S)

11. SPONSOR/MONITOR'S REPORT

NUMBER(S)

12. DISTRIBUTION/AVAILABILITY STATEMENT

Approved for public release; distribution unlimited

13. SUPPLEMENTARY NOTES

14. ABSTRACT

See attached.

15. SUBJECT TERMS

16. SECURITY CLASSIFICATION OF:

a. REPORT

unclassified b. ABSTRACT

unclassified c. THIS PAGE

unclassified
17. LIMITATION OF ABSTRACT

Same as

Report (SAR)
18. NUMBER 19a. NAME OF

OF PAGES RESPONSIBLE PERSON

21 


\section{ABSTRACT}

$\begin{array}{ll}\text { AUTHOR: } & \text { Mr. Dennis R. Sundell } \\ \text { TITLE: } & \begin{array}{l}\text { Globalization and the Military Industrial Base: Where Should U.S. Policy } \\ \text { Go? }\end{array} \\ \text { FORMAT: } & \text { Strategy Research Project } \\ \text { DATE: } & 9 \text { March } 2007 \quad \text { WORD COUNT: } 5,577 \quad \text { PAGES: } 21 \\ \text { KEY TERMS: } & \text { Global Supply Chain, Foreign Dependency } \\ \text { CLASSIFICATION: } & \text { Unclassified }\end{array}$

The collapse of the Soviet Union and the corresponding post cold war wave of globalization have served as the stimulus to the evolution of the U.S. military industrial base. While the prospects of globalization have provided the defense industrial base with rewards including reduced costs as a result of competition and greater access to foreign technologies it has also created some threats. Some of those threats include the potential to equip hostile nations with advanced weapons and technologies, loss of certain domestic defense capabilities and technologies and a dependence on foreign sources of supply. This project highlights two of those vulnerabilities which include global supply chain interdependency and the competition for the global "brain trust". While recommendations are offered as partial solutions to the identified vulnerabilities they highlight the broader issue which is that policymakers must adapt to a $21^{\text {st }}$ century way of conducting business to harness globalized industrial behavior in order to ensure the continued security and long term economic prosperity of the U.S. 



\section{GLOBALIZATION AND THE MILITARY INDUSTRIAL BASE: WHERE SHOULD U.S. POLICY GO?}

One of the critical functions of the United States Government is to provide for the common defense of the nation. This core task is a pillar of our constitution and throughout history our nation has looked to its leaders to protect and defend the sovereignty and democratic ideals of this nation. The post cold war wave of globalization has created some new and unique challenges to our nation's security. Today's defense must be created in this new era of globalization. The challenge for policymakers is to understand this phenomenon in order to make the appropriate changes in procedures, processes, and polices to ensure our continued security. As Jessica T. Mathews writes,

National governments are not simply losing autonomy in a globalizing economy. They are sharing powers-including political, social and security roles at the core of sovereignty-with businesses, with international organizations, and with a multitude of citizen groups, known as nongovernmental organizations. ${ }^{1}$

Without governmental intervention the ability of the state to control its economy will fade, and it is likely to become weaker across the board, leading to a major, perhaps revolutionary, transformation of the global security system. ${ }^{2}$

In order to understand the "way-ahead" it is important to understand the events leading the United States to where it is today. The fall of the Berlin Wall and the corresponding collapse of the Soviet Union served as the key stimulants to the evolution of the military industrial base. The significance of these events is highlighted by Thomas Friedman, who noted,

It tipped the balance of power across the world toward those advocating democratic, consensual, free-market-oriented governance, ... with the fall of the wall, there was only one system left and everyone had to orient them self to it ... Henceforth, economies would be governed from the ground up, by interests, demands, and aspirations of the people, rather than from the top down. ${ }^{3}$

This effort assumes the continuance of free-market economics and competition. It also assumes the continuance of the national goal of providing the military with the best equipment and technology possible at the best possible prices. The final assumption is that globalization is a fact, not something to be accepted or denied but rather, something that must be dealt with. While it is beyond the scope of this paper to address all the issues and concerns with globalization, examination of the global supply chain and the global competition for the "brain trust" will highlight the need for U.S. policy reform given the irreversible trends of globalization. 


\section{Globalization}

Globalization is not a new concept; however, the post cold war wave of globalization has brought about some unique characteristics which are truly unprecedented. The advances in communication and transportation technologies coupled with a free market ideology allow an unprecedented mobility for goods, services, and capital flows. U.S. policy has embraced and promotes the leveraging of these opportunities. The argument posits that the expansion of trade, investment and information sharing improves the quality of life for people globally. Empowered populations advance democratic ideals such as capitalism and liberty. In turn those populations' system of governance becomes more democratic. Democratic governments make better global partners and are less likely to turn to armed conflict and are better able to deal with the challenges they face. One tenant of the 2002 United States National Security Strategy argued for a new era of global economic growth through free markets and free trade. Specifically, to expand economic liberty and prosperity, the United States promotes free and fair trade, open markets, a stable financial system and the integration of the global economy. ${ }^{4}$ The 2006 National Security Strategy states that the U.S. has seized the global initiative, continues to press for more regional and bilateral and trade initiatives and furthers initiatives for more open markets, financial stability, and deeper integration of the world economy. ${ }^{5}$

The opportunities presented from globalization appear far reaching, policymakers have acknowledged that these opportunities have created challenges. Challenges include; exploitation of poorer populations, environmental destruction, and corrosion of social order in selected nation states. While acknowledgment is a step in the right direction there is little evidence suggesting policymakers have made any headway in addressing the problems. On the contrary industries response to globalization has been predictable and simple. They have leveraged the existing environment to continuously search for markets, capital, labor and ultimately profits. ${ }^{6}$ For policymakers the challenge has been their lack of ability to adjust as quickly as business thus creating a gap within the system. ${ }^{7}$ Policymakers must devise policies which leverage corporate drivers, to shape their behavior to harness globalization in order to ensure continued U.S. security and economic prosperity. ${ }^{8}$

Globalization has provided the U.S. and the defense industrial base with rewards. It has provided the Air Force with more "bang for the buck" as competition has forced costs down and quality up. ${ }^{9}$ It has strengthened overall U.S. military capabilities by providing greater access to foreign technologies and improved the financial health of the U.S. defense industry. ${ }^{10}$ Globalization has also created some threats, including the potential to equip hostile nations and groups with advanced weapons and technologies designed by the U.S. Technology transfers 
become increasingly more difficult with globalization because they are a desire of many crossborder relationships. ${ }^{11}$ Other threats from globalization include loss of certain domestic defense capabilities and technologies along with an associated dependence on foreign sources of supply and foreign control over U.S. industry. ${ }^{12}$

In order to understand where we are we must look at where we have been. The stimulant was the collapse of the Soviet Union. America's response was a "peace dividend" in the form of a $\$ 100$ billion dollar reduction in the defense budget. The post "Regan Defense Build-Up" resulted in defense industry consolidation of significant proportions. In less than a decade, what had been well over 50 major defense suppliers (prime contractors and large subcontractors) had been consolidated into only half-dozen, dominant defense firms. ${ }^{13}$ Consolidation continued ultimately limiting the number of suppliers to only 2 or 3 in each "critical" sector of the defense industrial base (e.g. aircraft, shipbuilding). Defined by the Defense Production Act, as materials that would be necessary to supply the military, industrial, and essential civilian needs of the United States during a national security emergency, and are not found or produced in the United States in sufficient quantities to meet such need, therefore, are vulnerable to the termination or reduction of the availability of the material. ${ }^{14}$ These limited numbers of suppliers remain today.

While the consolidation of the defense industry continued, globalization entered the scene. The driving factor was performance, but also lower costs helped the profitability of the remaining defense firms. While domestic defense budgets declined the same was true for our western allies who found themselves in a similar situation. Other considerations supporting globalization included a strategic shift in the way future wars would be fought, specifically, that the United States would not enter conflicts without coalition partners (e.g. Bosnia, Desert Shield, and Desert Storm). Another supporting factor of that strategy was the consideration that coalition interoperability would increase military effectiveness. The driving economic consideration was that globalization would provide economies of scale for dwindling defense budgets both here and abroad. While globalization moved forward, the ailing defense industry, leveraged globalization by outsourcing, supply-chaining and off-shoring non-core business to boost bottom-line performance.

The terrorist attacks on the United States on September 11, 2001 and the resultant U.S. led Global War on Terrorism have caused a reversal in U.S. defense spending. The $2007 \$ 489$ billion dollar U.S. defense budget represents about half the world's military spending thus making the United States a "new" and attractive market. ${ }^{15}$ "This opportunity has been one driver behind off shoring and the establishment of U.S. operations by European defense firms." ${ }^{16}$ It is, 
therefore, no surprise that defense companies world-wide are currently trying to access the U.S. defense market.

The aforementioned evolution describes the strategic factors contributing to the current U.S. defense industrial base. However, an understanding of the economic and supply chain interconnectivity resulting from globalization is important to better comprehend the strategic implications of this phenomenon. The Annual Industrial Capabilities Report to Congress, dated February 2006, states that the U.S. aerospace and defense industry had a foreign trade surplus of $\$ 31$ billion dollars in 2004 offering that the U.S. sells significantly more defense articles than it buys. Further, it offers recent Government Accountability Office (GAO) analysis, that between 2000 and 2004, U.S. defense exports averaged $\$ 11.5$ billion dollars per year, versus imports of $\$ 1.8$ billion dollars per year (Table 1$)^{17}$.

\begin{tabular}{|c|c|c|c|}
\hline $\begin{array}{c}\text { Calendar } \\
\text { Year }\end{array}$ & $\begin{array}{c}\text { Defense } \\
\text { Exports } \\
\text { (Billions) }\end{array}$ & $\begin{array}{c}\text { Defense } \\
\text { Imports } \\
\text { (Billions) }\end{array}$ & $\begin{array}{c}\text { Imports } \\
\text { as \% of } \\
\text { Exports }\end{array}$ \\
\hline 2000 & $\$ 10.70$ & $\$ 1.50$ & $14 \%$ \\
\hline 2001 & $\$ 11.60$ & $\$ 1.60$ & $14 \%$ \\
\hline 2002 & $\$ 11.80$ & $\$ 1.90$ & $16 \%$ \\
\hline 2003 & $\$ 11.60$ & $\$ 1.70$ & $15 \%$ \\
\hline 2004 & $\$ 11.90$ & $\$ 2.10$ & $18 \%$ \\
\hline
\end{tabular}

Table 1.

Examination of imports as a percentage of exports is insufficient to make substantial observations regarding economic and supply chain interdependency. Even after examining the GAO report in detail it does not quantify the depth of imports being used in military material. One reason is that the GAO discounts all suppliers below the second tier. This report is typical of existing governmental analysis regarding supply chain interdependency. This indicates a vulnerability to the security of the U.S. and will be developed further.

Examination of the evolution of the defense industrial base also highlights the second area of concern which is the competition for the global "brain trust". The consolidation of the defense industry has created difficulty in attracting high technology research scientists and engineers for a multitude of reasons to include the reduction in demand for high profit large scale production runs vice lower profit cost plus projects. Compounding the problem has been a decades worth of reduction in the nations Research and Development (R\&D) budgets. While off-shore, the effect of globalization has been an increase emphasis and investment by other nation states on technological development.

Since World War II the U.S. has derived much of its strength and power from being the global leader in science, technology and innovation. A conscience decision was made then to 
use private sector technology to defeat Soviet quantity. If that role remains a national objective, policymakers must take action to reverse the negative trends that exist in America's science, technology, engineering and mathematics (STEM) workforce. In today's globalized knowledge based environment the competition for innovation and creativity is a vulnerability to our long term security.

\section{Vulnerabilities For Policymakers}

The GAO report is an indicator that the government does not know to any real degree the depth of the global supply chain interdependency. In order to fully understand the issue it is important to look across all government agencies at the various industrial base studies to determine the depth of the problem.

One of the first studies on U.S. reliance of foreign suppliers for critical components in weapons systems was conducted by the Commerce Department and released in $1992 .^{18}$ The study examined the following three Navy systems; the HARM (high-speed anti-radiation missile), the Mark-48 ADCAP (advanced capabilities) torpedo, and the Verdin communication system. ${ }^{19}$ Almost 12,000 companies participated in the study and the research identified 115 distinct items where a foreign dependency existed, including high-tech items such as semiconductor ceramic packaging and needle roller bearing wire rod."20

A 2001 Department of Defense (DoD) study collected and evaluated information on eight different weapons systems. The principle conclusions of the study were: That foreign sources provided limited amounts of material and utilization of these foreign sources for these programs did not impact long term readiness. Further, that use of foreign sources did not impact the economic viability of the national technology and industrial base, and in most cases, domestic suppliers were available for the parts, components, and materials provided by foreign sources. ${ }^{21}$ While the conclusions sound reassuring the response rates from the subcontractors do not justify them for the following reasons: The responses were all voluntary, the average response rate for first tier contractors was 58 percent, 39 percent for third tier subcontractors, and DoD sought no response from fourth, fifth and lower level subcontractors. ${ }^{22}$ The results of this study are further negated when applying the diamond shaped supply matrix found in the Commerce study because it is at those lower tier levels where the majority of low cost commodity items are imported from foreign sources.

The depth to which America's dependence on low cost commodity goods from foreign sources is highlighted from a U.S. Department of Commerce study which examined goods imported into the United States where related trade constituted 50 percent or more of the value. 
The commodity categories include the complete spectrum of materials used in defense production such as electronic and semiconductor, motor vehicle parts, medical equipment, engines, metalworking machinery, etc. Additionally, related trade accounts for 46 percent of all basic chemicals and 47 percent of all industrial machinery imported into the United States. ${ }^{23}$ The commodity categories in this study highlight that the United States Government does not know to any significant degree where many components used in military equipment are made. This is due in part by the fact that DoD does not normally mandate supplier selections to contractors, nor do they systematically track sources used by sub-tier suppliers. ${ }^{24}$

Barry Lynn, the former Executive Editor of Global Business magazine examined the growing dependence on foreign-based suppliers and reported that a large portion of America's premier corporations have transformed themselves into little more than "virtual companies" which rely on large and complex global supply chains. ${ }^{25}$ Lynn argues that Dell Computer, a leading U.S. computer manufacturer and defense contractor, is in reality nothing more than an assembler of foreign made components. ${ }^{26}$ While Dell assembles the 4,500 parts used in one of its finished products in the United States, those parts come from dozens of suppliers located in numerous countries throughout Asia. ${ }^{27}$ Lynn argues further that Dell only maintains inventory for four days of production which highlights the international supply chain dependency. ${ }^{28}$ The Dell example is not an isolated instance. U.S. global industrial interdependency is both wide and deep as evidenced by the beliefs of Andrew Grove, the former chairman of Intel, the largest manufacture of semiconductors in the world. Grove believes that the integration of manufacturing activities is so intertwined that it has made war between the United States and China impossible. ${ }^{29}$

His analysis highlights the present unique economic interdependencies between nation states and industry. Barry Lynn noted that it is the fundamental incompatibility of two great political-economic systems that are presently operating in parallel.

One is a global manufacturing system created by companies which act independently of national considerations. Beneath that lies an older system, comprising governments whose ways of thinking date back to a time when economies were largely national, when imports and exports were of raw materials and finished goods, and when the idea of a large, vital corporation moving its center of gravity abroad was unthinkable. ${ }^{30}$

By drilling down to the commodity level it becomes clear that on one hand, one of the U.S. strategic objectives of seizing the global initiative through deeper integration into the world economy has been largely successful, on the other hand it highlights that globalization has created a strategic vulnerability to U.S. security. The issue for policymakers is to determine how 
to use a global supply chain, to get the best technology at the lowest cost, while protecting core assets and assuring trustworthy products.

Another critical vulnerability resulting from globalization is the migration of the science, technology, engineering and mathematics (STEM) "brain trust" from the U.S. to various nations throughout the world. For well over half a century, the U.S. led the world in scientific discovery and innovation. It has been this global technological leadership which has served as a significant component to U.S. national security strategy. However, in today's globalized competitive world many nations are on pace to pass the U.S. in scientific excellence and technological innovation. ${ }^{31}$ Historically, federal support of science and engineering research in universities and national laboratories has been the stimulant to America's leadership role. However, in recent years federal investments in the physical sciences, math and engineering have not kept pace and have declined sharply as a percentage of gross domestic product. ${ }^{32}$ The criticality of significant research and development investment is not only important for U.S. economic strength but also for America's security as highlighted in the Hart-Rudman Commission on National Security in 2001:

...The government has seriously underfunfed basic scientific research in recent years....The inadequacies of our systems of research and education pose a greater threat to U.S. national security than any potential conventional war that we might imagine. American leadership must understand these deficiencies as threats to national security. If we do not invest heavily and wisely in rebuilding these core strengths, America will be incapable of maintaining its global position. ${ }^{33}$

Although the U.S. still leads the world in research that advantage is dissipating rapidly as other nations commit significant resources to improve their capacities. The National Science Foundation (NSF) provides a series of benchmarks which highlight the negative tends.

Educationally the U.S. is awarding undergraduate degrees in science and engineering (S\&E) less frequently than other nations. The U.S. has a smaller share of the worldwide total of S\&E doctoral degrees awarded annually than both Asia and Europe. Additionally, U.S. citizens in S\&E graduate studies had been on the decline since 1994 while enrollment of foreign born students has risen by 25 percent. In 2001 approximately 57 percent of all S\&E postdoctoral positions in U.S. universities were held by foreign scholars. ${ }^{34}$

Examining the workforce illuminates the fact that since 1980 the number of S\&E positions in the U.S. has grown at five times the rate of the workforce. While the number of S\&E degrees earned by U.S. citizens is growing at a rate less than the growth in the workforce and much less than the number of S\&E positions available. This fact is exacerbated by the increase in the global competition for those skills. For example, between 1993 and 1997 the Organization for 
Economic Development countries increased their number of S\&E research jobs by 28 percent, almost twice the 15 percent increase in research jobs in the U.S. ${ }^{35}$

The world's fastest growing economies are on track to catch and perhaps surpass U.S. $R \& D$ investment within the next few years (Figure 1).

TOTAL R\&D INVESTMENTS: FASTEST GROWING ECONOMIES

GAINING RAPIDLY ON U.S.

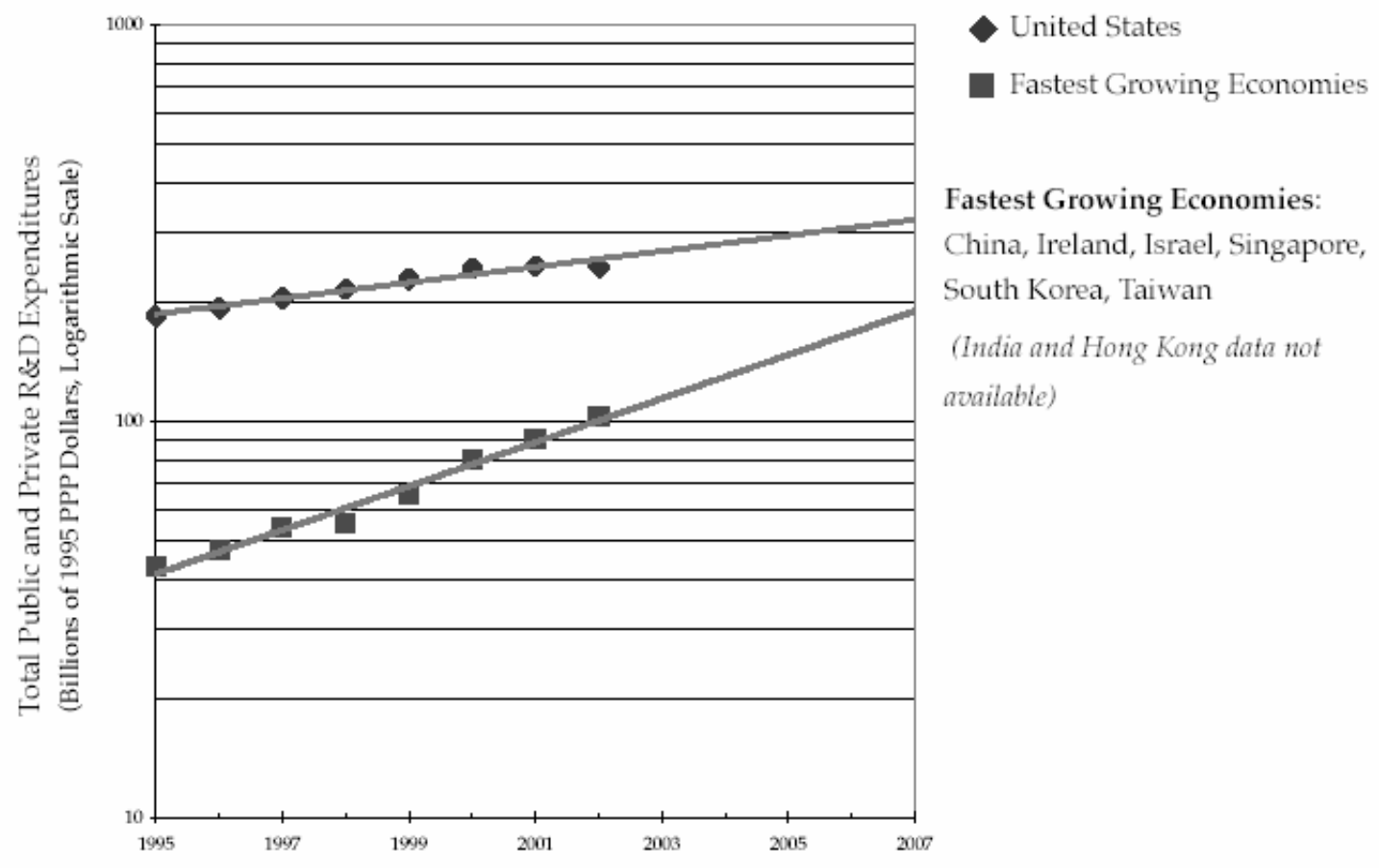

Source: Organisation for Economic Cooperation and Development, Main Science and Technology Indicators, May 2003. Compiled by the APS Office of Public Affairs

Figure 1.

U.S. federal funding of basic research in engineering and physical sciences has experienced negative growth over the past thirty years. As a percentage of Gross Domestic Product (GDP) it has been on a thirty year decline (Figure 2).

In the High-technology sector the U.S. share of worldwide high-tech exports is on the decline. From 1980 through 2001 the U.S. share fell from 31 to 18 percent while emerging Asian countries grew form 7 to 25 percent. These benchmarks highlight the fact that the "brain trust" of the U.S. is at risk. Historically, the U.S. leadership role in innovation, creativity, and technology has been a critical element to national security and America's global economic strength. Given the current globalized environment policymakers must take action if it is to preserve this core strength. 


\section{FEDERAL INVESTMENT IN PHYSICAL SCIENCES IN}

SIGNIFICANT DECLINE

Ratio of U.S. Federal Government Funding for Physical Sciences Research to U.S. Gross Domestic Product: 1970-2003

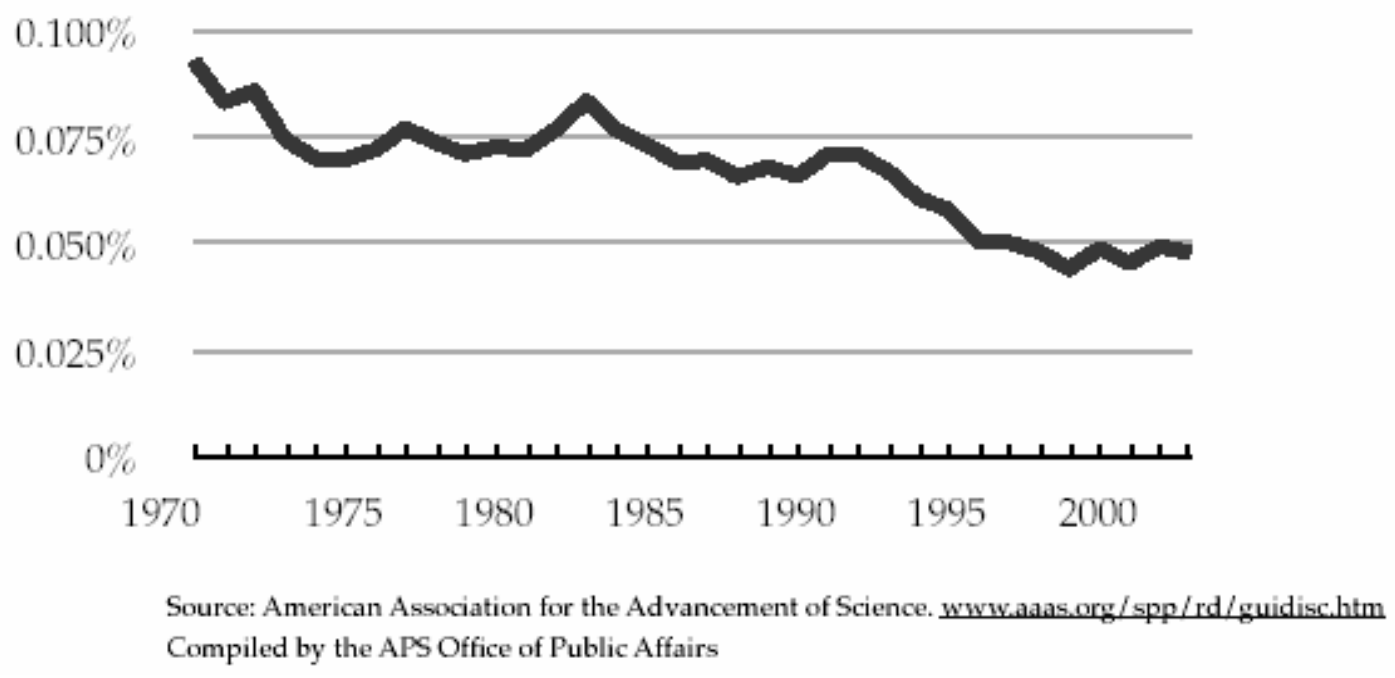

Figure 2.

The two vulnerabilities presented illuminate that globalization does have an impact on the security and long term economic prosperity of the U.S. In some regards the two vulnerabilities addressed represent opposite ends of the spectrum. The global supply chain represents a challenge for policymakers. If left unaddressed, the supply chain will continue to penetrate further into global supply lines exacerbating the "unknowns" associated with defense industrial base dependency. While not an immediate concern, the vulnerability of increased competition for the global "brain trust" is something that policymakers need to address in the near term given that the capability takes a significant amount of time to grow and effort to sustain.

\section{Analysis and Recommendations}

Supply chain vulnerability highlights the question as to how to use a global supply chain in order to get lower costs, yet structure it in such a way that protects core assets and provides trustworthy products? ${ }^{36}$ For policymakers the critical element in response to globalization is recognition that "one size does not fit all." 37 The greatest problems come from policy that is either disconnected from reality or misapplied. For example, having a 100\% (or even 50\%) "buy domestic" rule on cobalt, a critical mineral used in aircraft engines, would not work for the simple fact that all sources of cobalt are found outside the U.S. ${ }^{38}$ An example of a misapplied policy would be applying traditional efficiency metrics to basic research. The policy goal therefore is to 
look for policy disconnects do to globalization or the "one size fits all" mentality creating a misapplication. ${ }^{39}$

In order to facilitate the right policy response to globalization several actions need to occur. First, determine what provides an asymmetrical advantage, identifying specific elements of the defense industrial base, so that they can be prioritized in order to determine weather they need to be strengthened or defended. ${ }^{40}$ Second, understand the value chain of each industry sector. Specifically, determine weather it is important to strengthen or protect the raw component, the process, the machinery which produces the product, the subsystem provider or the integrator. ${ }^{41}$ Finally, the policy should differ depending upon how rapidly the technology is developing. For example, it may not be necessary to strengthen a technology with short development cycles because an investment in next generation could recover the competitive position. On the other hand a technology with very long development cycles may require more protection given that it may not be possible to recover from a lost leadership position. ${ }^{42}$

While it may be physically impossible it would also be fiscally impossible to monitor the global supply chain from the top to the commodity level in a traditional sense. Any traditional method would lag the global supply chain and hamper rather than help policy makers attempt to be proactive in today's environment. However, answering the questions above would do a great deal too align policy decision making with strategy execution. Although a daunting task at the outset once the data is collected a risk model could be developed to provide relevant current information regarding the global supply chain. The effort should focus on providing actionable risk information to policymakers. Decisions would be made with the best available information. This does not infer that decisions would be made with any less "political" impact but rather that present day global supply chain risk information would be available for consideration in the process. It is also important that the model be horizontally integrated as well as vertically integrated to account for major platforms through individual item analysis. As previously stated the post cold war industrial base left very few major platform defense contractors. The U.S. Defense Aerospace Industry is representative of one of those industries. Due to low production rates, expense and complexity of the systems the Defense Aerospace Industry is one of the most globalized.

In order to offer a recommendation as to what agency should have oversight responsibility of the risk analysis model a brief examination of the existing regulatory framework is important. Because the authority, influence and interest of different agencies may affect the ability of the U.S. to pursue its objectives of pursuing globalization and balance national security. Section 38 of the Arms Export Control Act authorizes the President to control the export and import of 
defense articles and defense services. The statutory authority of the President to promulgate regulations with respect to exports of defense articles and defense services was delegated to the Secretary of State by Executive order $11958 .{ }^{43}$ By virtue of delegations by the Secretary of State, these regulations are primarily administered by the Director of the Office of Munitions Control, Bureau of Politico-Military Affairs, Department of State. ${ }^{44}$ The primary regulation which controls unclassified defense-related trade and technology transfers resides in the International Traffic in Arms Regulations (ITAR). The ITAR governs all military Security Assistance and International Armaments Cooperation programs. Within the ITAR is the U.S. Munitions List (USML), which includes all goods, services, and technologies designated as defense related. ${ }^{45}$ Exports of USML items or technologies must be licensed by the Office of Defense Trade Controls (DTC), a division of the State Department's Bureau of Political and Military Affairs. ${ }^{46}$ Exports not on the USML are generally under the regulatory jurisdiction of the Department of Commerce. The Export Administration Act of 1979 (EAA 1979) controls the transfer of technologies which have dual-use, both commercial and military application. ${ }^{47}$ With regard to regulating foreign ownership, control and influence (FOCI) of the U.S. industrial base there are two key policy controls. The first is the Committee on Foreign Investment in the U.S. (CFIUS) which oversees proposed foreign mergers with and acquisitions of U.S. businesses. ${ }^{48}$ The second is the National Industrial Security Program (NISP) which governs U.S. classified information release during any phase of a U.S. government contract, license, certificate, or grant. $^{49}$ The final piece of relevant regulatory framework is the Federal Acquisition Regulation (FAR). The FAR was established to provide uniform policies for the acquisition of supplies and services by executive agencies. ${ }^{50}$ The FAR is maintained jointly in accordance with the Office of Federal Procurement Policy (OFPP) Reauthorization Act, under authorities granted to the Department of Defense (DoD), General Services Administration (GSA), and the National Aeronautics and Space Administration (NASA). ${ }^{51}$ On behalf of all three FAR issuing agencies the GSA Federal Acquisition Policy Division maintains the FAR and acts as the administrative support arm. ${ }^{52}$

Examination of the laws and regulations indicates a varying degree of support for U.S. political, military, economic and security objectives. In some instances regulations and policies place major limitations on exports with concerns about defense related trade and technology transfers and FOCl over key sectors of the U.S. industrial base. ${ }^{53}$ The other side of the argument seeks greater support for more International Armaments Cooperation programs and promotes Security Assistance programs encouraging allies and other friendly states to procure U.S. equipment. ${ }^{54}$ The situation creates a delicate balance between security, economic 
prosperity and continued proliferation of current U.S. national security strategies promoting globalization. The existing regulatory structure provides a degree of balance between the two arguments. The risk model argues that this issue is not an either or option but rather an attempt to provide more "real-time" information about the distributed global supply chain permitting better regulation of the system. The model should be maintained by the administrative support arm for the FAR, the GSA Federal Acquisition Policy Division. Within the construct of the existing regulatory framework they could provide the administrative and objective oversight requisite to maintain the balance between the interested parties. Additional "real time" information for policy makers would help close the gaps between industry and policy and provide a more efficient and effective balance between security and globalization. While this action would not fully resolve the global supply chain vulnerability; it would be a step in the right direction.

The competition for the global "brain trust," is a vulnerability of significant importance given the long lead time in the development and sustainment of the capability. While the benchmarks highlighted the decline in this national core competency there are several strategies to correct it in today's globalized world. One strategy is to have the best industrial policy in the world with the ability to guess correctly every time as to what sectors to defend or not. $^{55}$ The problem with this strategy is that it is unrealistic to consider that it could be sustainable over time resulting in an incorrect guess eventually. ${ }^{56}$ Analysis of the global supply chain highlights that point. An alternative strategy is to have a sufficiently robust economy which possesses a deep and wide pool of human, physical and intellectual capital capable enough to reallocate resources to meet all challenges. ${ }^{57}$ The critical element to success in this strategy is to invest in research and development which allows the economy to "run faster." 58 The enabler to accomplish that is investment in basic technology and product and process innovation. Given the thirty year decrease in federal funding of R\&D and the fact that the private sector now accounts for more than $68 \%$ of total R\&D expenditures in the U.S. the problem is that industrial investment focuses on short term results aimed at development vice long term basic research that would be funded by the federal government. ${ }^{59}$ Business has no incentive to fill that void. Defense industries incentive to invest their R\&D dollars is driven only when the probability of long term production runs are possible. The profit motive is their driver. Additionally, they have the globalization escape hatch where they can off shore the problem over seas to lower cost countries. ${ }^{60}$ This situation leaves only the U.S. government to fill the front end of the developmental process. This would be the Science and Technology (S\&T) portion of the federal R\&D budget. It is important to understand the difference between S\&T 
and development. Science and technology expenditures focus on the search for new knowledge. Science and technology research is typically designed to answer questions or fill gaps within existing bodies of knowledge. The effort may confirm or refine existing paradigms or contradict them, setting the stage for scientific revolution. On the contrary, development is a process in which a product or process is brought into being or improved based upon existing knowledge or theory. Unfortunately recent distribution of the federal R\&D budget focuses on development vice science and technology. The 2004 R\&D budget of 181 billion dollars had a distribution of 59 billion dollars in S\&T and the remaining 122 billion in development. The benchmark trends indicate that the level of federal support in S\&T is insufficient to reverse the downward indices.

The benchmarks highlighted the growing technological competition. From 1995 through 2001, the economies of China, South Korea and Taiwan increased their gross R\&D investments by 140 percent. During the same period the U.S. increased its investments by 34 percent. The 2006 Joint task force on Defense Critical Technologies highlights this fact and argues that the U.S. is experiencing a shortage in the number of citizen graduates able to support defense research programs and recommends efforts be taken to mitigate the problem. ${ }^{61}$ While there are potentially many alternatives to mitigating this vulnerability in terms of competing for the global "brain trust" the fact remains that if the U.S. government wants to preserve this historically U.S. core competency they will have to increase federal funding levels to fill the gaps of the predictable behavior of industry. Specifically those efforts must focus on increased resourcing the S\&T side of the R\&D equation. This would necessitate growth in basic research and the development of incentives and improvements throughout the entire U.S. education system.

Another recommendation to help alleviate the pending crisis is to lift the existing visa restrictions for foreign students. Historically, a large number of foreign students graduating from U.S. universities with degrees in STEM have remained here and been an important asset to our industrial workforce. In fact, one-third of today's U.S. workforce of scientists and engineers were born outside the U.S. ${ }^{62}$ The post 9/11 immigration controls resulted in a 32 percent drop in the number of international student applications in $2004 .^{63}$

\section{Conclusion}

The fall of the Berlin wall stimulated an evolution in the U.S. military industrial base. Its transformation continued through the events of 9/11 and globalization to the present. These events in concert with a more globalized world have been incorporated into the U.S. National Security Strategy (NSS). The 2002 U.S. NSS argued for ignition of a new era of global 
economic growth through free markets and trade. The 2006 NSS states that the U.S. has seized the global initiative and continues to press further for more open markets and deeper integration into the world economy. The argument for the long term benefits of globalization is sound. Not only are the economic advantages created by this phenomenon good for the U.S. the potential democratization of other nations offers hope as the world continues to become more interconnected.

While the opportunities that globalization offers are far reaching the facts are that it has also created vulnerabilities to U.S. security and long term economic prosperity. The challenge for policymakers is to determine how to deal with the phenomenon. The global supply chain and the competition for the global "brain trust" are two critical vulnerabilities that were highlighted. Those two vulnerabilities do not represent an all inclusive list but they do highlight the need for policy reform in this new wave of globalization. The recommendation of a risk analysis model to inform global supply chaining, off-shoring and out-sourcing is aimed on the immediate need to preserve significant core military capabilities. The recommendations to increase federal funding with a focus on basic research, education and revisiting foreign student visa laws are focused on planting seeds for the future to ensure our technological prowess into the future. Although aimed at mitigating risk those recommendations are only partial solutions to the broader issue which is that policymakers must adapt to a 21st century way of conducting business to harness globalized industrial behavior.

The pace and rate of change in the globalized environment require a change to held over cold war practices, procedures and policies. Without it gaps will widen and security and economic prosperity will become more vulnerable. Complex problems require imagination and innovation. The scenario infers that without action there are dangers. The competition created in the globalized world will require Americans to work harder, be smarter and move faster. This includes our policymaking institutions. Innovation has been a historically American trademark. The challenge to respond is here and the time to take action is now.

\section{Endnotes}

${ }^{1}$ Jessica T. Mathews, "Power Shift," Foreign Affairs (January-February 1997), 50.

${ }^{2}$ Martin van Creveld, The Rise and Decline of the State (Cambridge, UK: Cambridge University Press, 1999), vii.

${ }^{3}$ Thomas L. Friedman, The World is Flat (New York: Farrar, Straus and Giroux, 2005), 49. 
${ }^{4}$ George W. Bush, The National Security Strategy of the United States of America (Washington D.C.: The White House, March 2006), 25.

${ }^{5}$ Ibid., 26.

${ }^{6}$ Pierre A. Chao, The future of the U.S. Defense Industrial Base: National Security Implications of a Globalized World (Washington D.C., Center for Strategic and International Studies (CSIS), 2 June 2005). CSIS paper presented at the National Security Series and national Defense University Foundation.

${ }^{7}$ Ibid.

8 Ibid.

${ }^{9}$ Mark A. Lorell, et. al., Going Global? U.S. Government Policy and the Defense Aerospace Industry (Santa Monica, CA: RAND, 2002), xvii.

${ }^{10}$ Ibid.

${ }^{11}$ Ibid.

12 Ibid.

${ }^{13}$ Lynne C. Thompson and Sheila R. Ronis, The U.S. Defense Industrial Base, National Security Implications of a globalized world (Washington D.C.: National Defense University Press, 2 June 2005), 12.

${ }^{14}$ Appendix A: Section 309 of the Defense Production Act, Part IX, sec. 901. (2003)

${ }^{15}$ Chao

${ }^{16}$ Chao

${ }^{17}$ Department of Defense, Annual Industrial Capabilities Report to Congress (Washington, D.C.: Office of Under Secretary of Defense Acquisition, Technology and Logistics Industrial Policy, February 2006) 6.

${ }^{18}$ Pat Choate and Edward Miller, An Analysis: The US Industrial Base and China (Washington, D.C.: U.S. China Economic and Security Review Commission, 2003), 12.

${ }^{19}$ Ibid

${ }^{20}$ Ibid.

${ }^{21}$ Ibid.

22 Ibid.,13

${ }^{23}$ U.S. Commerce Department, U.S. Merchandise Trade: Imports for consumption for the Top Four-digit NAICS Codes, (Washington D.C.: U.S. Commerce Department, 7 May 2002) Exhibit four, 5-6. 
${ }^{24}$ Choate and Miller, 13.

25 Ibid., 7.

${ }^{26}$ Ibid.

${ }^{27}$ Ibid.

${ }^{28}$ Ibid.

${ }^{29}$.Barry Lynn, "Unmade in America, The true cost of a global assembly line," Harper's (June 2002): 10.

${ }^{30}$ Ibid.

${ }^{31}$ Task Force on the Future of American Innovation, The Knowledge Economy: Is the United States Losing its Competitive Edge? (Washington, D.C.: Task Force on the future of American Innovation, 16 February 2005), 1.

32 Ibid.

${ }^{33}$ The United States Commission on National Security/21 ${ }^{\text {st }}$ Century, Road Map for National Security: Imperative for Change: The Phase III Report of the U.S. Commission on National Security/21 $1^{\text {st }}$ Century (Washington, D.C.: The United States Commission on National Security $/ 21^{\text {st }}$ Century, January 2001), ix; available from http://www.au.af.mil/au/awc/awcgate/nssg/phaselllfr.pdf

34 "National Science Foundation Ind. Appdx., Table 2-12" located in Task Force on the Future of American Innovation, The Knowledge Economy: Is the United States Losing its Competitive Edge? (Washington, D.C.: Task Force on the Future of American Innovation, 16 February 2005), 4.

35 "National Science Foundation Ind. 2004, Researchers in OECD Countries, by country/region, 1993, 1995 and 1997, fig. 3-29" located in Task Force on the Future of American Innovation, The Knowledge Economy: Is the United States Losing its Competitive Edge?

(Washington, D.C.: Task Force on the Future of American Innovation, 16 February 2005), 6.

${ }^{36}$ Jim Lewis, Center for Strategic and International Studies, e-mail message to author, 14 November 2006.

${ }^{37}$ Chao.

${ }^{38}$ Chao.

${ }^{39}$ Chao

${ }^{40}$ Chao.

${ }^{41}$ Chao

${ }^{42}$ Chao 
${ }^{43}$ Title 22 Foreign Relations, U.S. Code Chap.I, Subchap.M, Sec. 120.1(a), (1 April 1992).

${ }^{44}$ Ibid.

${ }^{45}$ Lorell, et. al., xvii.

${ }^{46}$ Ibid.

${ }^{47}$ Ibid. xviii.

${ }^{48}$ Ibid.

${ }^{49}$ Ibid.

${ }^{50}$ General Services Administration, Federal Acquisition Regulation, available from http://www.arnet.gov/far/authorityframe.html; internet accessed 8 February 2007

51 Ibid.

52 Ibid.

${ }^{53}$ Lorell, et. al., xviii.

${ }^{54}$ Ibid.

${ }^{55}$ Chao.

56 Ibid.

57 Ibid.

${ }^{58}$ Ibid.

${ }^{59}$ National Science Foundation Ind. 2004, Fig. O-3

http://www.nsf.gov/sbe/srs/seind04/c0/fig00-03.htm and Lieberman White Paper, May 2004, p. 15 and http://lieberman.senate.gov/newsroom/ whitepapers/Offshoring.pdf and PCAST Report, Oct. 2002, http://www.ostp.gov/PCAST/ INAL\%20R\&D\%20REPORT\%20WITH\%20LETTERS.pdf

${ }^{60}$ Chao.

61 Joint U.S. Defense Science Board and UK Defense Scientific Advisory Council, Task Force on Defense Critical Technologies ( Washington, D.C.: U.S. Defense Science Board, March 2006), 115.

${ }^{62}$ Council on Competitiveness, National Innovation Initiative Report: Innovate America (Washington, D.C.: Council on Competitiveness, December 2004): 19.

63 Ibid. 
